\title{
Soil nutrient status of the Bay of Plenty region and the implications to pasture productivity and fertiliser requirements
}

\section{S.F. LEDGARD'1, T.J.M. JOHNSTON² ${ }^{2}$ D.C. EDMEADES' and D.M. WHEELER' ${ }^{1}$ MAF Ruakura Agricultural Centre, Private Bag, Hamilton ${ }^{2}$ BOP Fertiliser Ltd. Private Bag, Mount Maunganui South}

\begin{abstract}
The soil nutrient status of sheep and beef, and dairy farms in the Bay of Plenty region was examined using results from over 4700 soil samples analysed by MAF between 1988 and 1991. The proportion of farms in various soil test categories was determined and related (using known relationships) to the potential responsiveness of pastures to fertiliser nutrient additions. About $70 \%$ of farms had soil phosphorus (P) tests below optimum values, indicating that pasture production would be increased by addition of $\mathrm{P}$ fertiliser on these farms. Similarly,about $50 \%$ of farms hadbelow-optimum levels of sulphur (S) and potassium (K). Pasture production on most farms was limited by more than one nutrient and a relatively high proportion of pumice soils had low levels of $\mathrm{P}, \mathrm{S}$ and $\mathrm{K}$. Pumice soils are prone to large leaching losses of added sulphate $\mathrm{S}$ and field experimental results indicated that elemental $S$ (in sulphur superphosphate) was more efficient at increasing pasture production on these soils than sulphate $S$ (in superphosphate). Soil test data was also used to indicate that about onethird of sheep and beef, andone-half of dairy farms were suitable for use of slow-release reactive phosphate rock (RPR) as a source of $\mathrm{P}$, as indicated by soil $\mathrm{pH} \leq 6.0$ and $\mathrm{MAF}$ fertiliser $\mathrm{P}$ requirements at or above maintenance levels.
\end{abstract}

Keywords soil test, fertiliser requirement, phosphorus, sulphur, potassium, slow-release fertiliser

\section{Introduction}

Fertiliser use within the Bay of Plenty (BOP) region has fluctuated greatly during the past decade and was low during 1986-88. This is likely to have influenced productivity of farms where fertiliseruse had decreased or stopped for a number of years (eg. O'Connor et al. 1990).

Soil testing is the simplest and most cost-effective procedure for determining the requirements for major fertiliser nutrients and lime to maintain or increase pasture production. In N ew Zealand, the MAF soil tests have been calibrated using a large number of field experiments. Thus the pasture responsiveness to addition of a fertiliser nutrient or lime is known for a given soil test level (Edmeades et al. 1984; Edmeades et al. 1988; Sinclair et al. 1985).

This paper reports soil test levels on almost 1500 sheep and beef (hereafter called sheep) and dairy farms in the BOP, and discusses their implications to pasture productivity relative to potential and to the applicability of various fertiliser forms.

\section{Methods}

A database of soil tests analysed by the MAF Soil Fertility Service between 1988 and 1991 for the BOP and North Island was compiled. Soil samples from the BOP had been submitted from an area encompassing Tauranga, Whakatane and Rotorua and induded 1557 samples from 531 sheep farms and 3228 samples from 966 dairy farms.

Soils had been submitted for analysis by farmers, consultants (MAF and private) and fertiliser company representatives. They were analysed for $\mathrm{pH}$, Olsen $\mathrm{P}$, K, S, Ca and Mg (Comforth \& Sinclair 1984).

Table 1 Optimum soil test values for sheep/beef and dairy farms. These are based primarily on achieving approximately 90 and $\mathbf{9 5 \%}$ respectively of biological maximum production.

\begin{tabular}{lcc}
\hline & Sheep/beef & Dairy \\
\hline $\mathrm{P}^{\prime}$ & $15-20$ & $25-30$ \\
$\mathrm{~S}$ & $7-10$ & $6-12$ \\
$\mathrm{~K}$ & $6-6$ & $\mathbf{8 - 1 0}$ \\
$\mathbf{M g}^{2}$ & $7-10$ & $9-12$ \\
$\mathrm{pH}$ & $5.7-6.0$ & $\mathbf{5 . 8 - 6 . 0}$ \\
\hline
\end{tabular}

1 Optimum is lower for low $P$ retention soils and higher for high $\mathrm{P}$ retention (e.g. ash) soils.

2 Optimum for pasture growth only.

For each farm type (sheep and dairying), soil test results were classified by soil type and the proportion of samples within specific ranges of soil test values 
were obtained. These ranges of soil test values were related to the expected level of pasture productivity relative to the potential, using known relationships (Table 1; Comforth \& Sinclair 1984; Edmeades et al. 1988; Sinclair et al. 1985). The suitability of slowrelease fertilisers was also examined using soil data for reactive phosphate rock (RPR) and using research results for elemental $\mathrm{S}$.

\section{Results and Discussion}

Soil analyses

Most samples from the BOP region were from yellow brown pumice ('pumice'), recent and yellow-brown loam ('ash') soils (Table 2). A small proportion of samples was from dairy farms on organic ('peat') soils.

Table 2 Percentage of soils sampled from the Bay of Plenty between 1988 and 1991 with MAF test values below optimum.

\begin{tabular}{|c|c|c|c|c|c|c|}
\hline \multicolumn{7}{|c|}{ Sheep and beef larms: } \\
\hline Soil & No. & $P<17$ & $S<6$ & $K<5$ & $M g<6$ & $\mathrm{pH}<5.6$ \\
\hline pumice & 975 & 87 & 70 & 52 & 12 & 14 \\
\hline ash & 279 & 60 & 34 & 57 & 10 & 30 \\
\hline recent & 171 & 30 & 41 & 12 & 0 & 8 \\
\hline all & 1548 & 71 & 57 & 46 & 9 & 16 \\
\hline
\end{tabular}

\section{Dairy farms:}

\begin{tabular}{lrccccc} 
Soil & No. & $P<26$ & $S<8$ & $K<8$ & $M g<9$ & $p H<5.7$ \\
\hline pumice & 2073 & 93 & 53 & 71 & 35 & 32 \\
ash & 246 & 61 & 12 & 50 & 9 & 38 \\
recent & 555 & 53 & 52 & 49 & 2 & 29 \\
peat & 216 & 55 & 25 & 88 & 6 & 36 \\
all & 3198 & 76 & 47 & 66 & 24 & 31 \\
\hline
\end{tabular}

Table 1 summarises desirable optimum soil test levels based on field trial results and Table 2 identifies the proportion of farms in the BOP below optimum levels. Farms within these categories are likely to show increases in pasture production from addition of nutrient(s) in fertiliser.

Over all soils on sheep farms, $\mathrm{P}$ was the main nutrient limiting pasture production (about $70 \%$ below optimum soil $\mathrm{P}$ levels). About half of these soils had low $S$ and $K$ soil tests, while only a small proportion had below-optimum levels of $\mathrm{Mg}$ and $\mathrm{pH}$. The relative importance of nutrients varied with soil type. The most obvious differences were a larger proportion of pumice soils low in $P$ and $S$, few recent soils low in $K$, and a larger proportion of ash soils with low $\mathrm{pH}$.

Dairy farms showed similar results to those for sheep farms, although a larger proportion of dairy farms were below optimum for $\mathrm{K}$ and a smaller proportion were below optimum for S. Potassium was limiting on a larger proportion of peat soils on dairy farms than for other soil types.

In general, the proportion of farms below optimum soil test levels in the BOP was similar to that for the whole of the North Island (compare Tables 2 and 3). However, in the BOP there was a relatively higher proportion of samples with below-optimum soil $\mathrm{P}, \mathbf{S}$ and $\mathrm{K}$ tests on sheep farms and below-optimum $\mathbf{S}$ tests on dairy farms. This was largely due to the high component of pumice soils in the BOP, which had lower $P, S$ and $K$ test values on average than most other soils.

Table 3 Percentage of soils sampled from the North Island between 1988 and 1991 with MAF test values below optimum.

\begin{tabular}{|c|c|c|c|c|c|c|}
\hline \multicolumn{7}{|c|}{ Sheep and beef farms: } \\
\hline Soil & No. & $P<17$ & $S<6$ & $K<5$ & $M g<6$ & $\mathrm{pH}<5.6$ \\
\hline pumice & 2295 & 83 & 76 & 47 & 11 & 13 \\
\hline ash & 2511 & 60 & 16 & 30 & 3 & 20 \\
\hline recent & 705 & 22 & 37 & 16 & 2 & 15 \\
\hline all & 11349 & 40 & 42 & 26 & 3 & 23 \\
\hline \multicolumn{7}{|c|}{ Dalry farms: } \\
\hline Soil & No. & $P<26$ & $S<8$ & $K<8$ & $M g<9$ & $\mathrm{pH}<5.7$ \\
\hline pumice & 2506 & 93 & 51 & 77 & 42 & 30 \\
\hline ash & 7089 & 62 & 8 & 67 & 9 & 17 \\
\hline recent & 1503 & 54 & 45 & 61 & 10 & 30 \\
\hline peat & 1218 & 48 & 35 & 87 & 15 & 50 \\
\hline all & 17385 & 65 & 26 & 67 & 13 & 24 \\
\hline
\end{tabular}

\section{Potential responsiveness to added nutrients}

Table 4 indicates the potential increases in pasture production that can be expected for 3 categories of soil test values for the 3 major nutrients, and the proportion of farms in these categories. Farms in the first category for each nutrient are essentially in the 'development phase' of soil nutrient status. These farms are highly responsive (increase of $10-30 \%$ expected) and nutrient addition in fertiliser should be very profitable within the year of application (eg. Ledgard et al. 1991; Roberts et al. 1991). although this may require an increase in stocking rate to ensure high utilisation of extra feed grown due to fertiliser. The second category is moderately responsive andnutrient additionshould also be profitable in the short-term (I-3 years), particularly on dairy farms. The third category represents the 'maintenance phase' of soilnutrient status where responses to fertiliser addition are small $(0-10 \%)$ and fertiliser is applied to sustain productivity. Thus, on sheep farms in this category the economics of $\mathrm{P}$ application must be considered in the longer-term with the 'break even' time for profitability being about 3-6 years (Clark et al. 1990). However, on dairy farms in this third category, fertiliser addition can 
beeconomicallyworthwhilewithiitheyearofapplication on intensively managed farms (Roberts $\boldsymbol{e t}$ al. 1990).

Table 4 Percentage of farms in the Bay of Plenty within various soil test ranges categ orised according to the expected responsiveness to nutrient addition itt fertiliser.

\begin{tabular}{|c|c|c|c|c|}
\hline \multirow[t]{2}{*}{ Nutrient } & \multirow{2}{*}{$\begin{array}{l}\text { Soil test } \\
\text { values }\end{array}$} & \multirow{2}{*}{$\begin{array}{l}\text { Approx. increase } \\
\text { in production (\%) }\end{array}$} & \multicolumn{2}{|c|}{$\%$ of farms sampled } \\
\hline & & & Sheep & Dairy \\
\hline \multirow[t]{3}{*}{$P$} & cl3 & 15 & 55 & 30 \\
\hline & $13-17$ & 10 & 15 & 20 \\
\hline & $17-25$ & 5 & & 20 \\
\hline \multirow[t]{3}{*}{$\mathbf{S}^{1}$} & $<4$ & 15 & 35 & 15 \\
\hline & $4-6$ & 10 & 30 & 25 \\
\hline & $7-9$ & 5 & & 10 \\
\hline \multirow[t]{3}{*}{ K } & $<3$ & 15 & 10 & 10 \\
\hline & $3-4$ & 10 & 40 & 20 \\
\hline & $5-6$ & 5 & & 40 \\
\hline
\end{tabular}

Sites with rainfall $<1500 \mathrm{~mm}$. In higher rainfall sites on pumice soils, large (e.g. 20-50\%) pasture responses to $S$ are common and soil $S$ test may not be a good indicator (B.S. Thorrold, unpublished data).

$P$ is the most expensive of the major nutrients (e.g. about $5 x$ cost per $\mathrm{kg} \mathbf{S}$ and $3 x$ cost per $\mathrm{kg} \mathrm{K}$ ). Thus, a larger increase in production from $P$ is required for profitability relative to the other nutrients. Levels of $\mathbf{P}$, $\mathrm{S}$ and $\mathrm{K}$ can be varied to obtain the most economic response from all nutrients.

Clearly, more farms are in the very responsive category for $P$ than for $S$ or $K$. Thus. about $50.70 \%$ of farms are in the combined categories (1 and 2 for sheep and I-3 for dairying) where application of P, S or K (depending on individual soil tests) can be economically worthwhile in the short-term (1-2 years).

\section{Fertiliser requirements}

Major nutrients

Soil test data from BOP farms were used in the MAF fertiliser recommendation models and the results indicated that few farms required only one of the major nutrients $P, K$ or $\mathbf{S}$ (Table 5). Only $5 \%$ of farms had no requirement for fertiliser. Thus, most farms required combinations of fertilisernutrients eg. about onequarter required $\mathrm{P}+\mathrm{S}$ on sheep farms whereas $\mathrm{P}+\mathrm{K}$ was relatively more important on dairy farms. About onehalf of all farms had a recommendation for $\mathrm{P}+\mathrm{S}+\mathrm{K}$.

Average rates of nutrients required for the current year's production and for longer-term maintenance of production are summarised in Table 6. Current requirements were calculated from maintenance requirements using an adjustment for measured soil test values relative to desirable values (Cornforth $\&$ Sinclair 1984). Thus, on sheep farms, the relatively low soil $P$ test values (Table 2) have resulted in current requirements for $\mathrm{P}$ being, on average, $16 \%$ above the longer-term maintenance requirements over all soils. On pumice soils, this value was over $40 \%$ (Table 6 ).

Table 5 Percentage of farms in the Bay of Plenty with recommendations for various combinations of $P, S$ and $K$ according to MAF fertiliser recommendation models.

\begin{tabular}{lcc}
\hline Nutrients recommended & Sheep/beef & Dairy \\
\hline No fertiliser & 5 & 5 \\
P only & 6 & 3 \\
S only & 7 & 5 \\
K only & 3 & 10 \\
P and S only & 22 & 6 \\
P and K only & 6 & 30 \\
P, S and K & 56 & 47 \\
\hline
\end{tabular}

Table 6 Average rates of $P, S$ and $K$ recommended for the current year and for 'long-term maintenance for the grazing area' of farms on pumice soil and on all soils in the Bay of Plenty, determined using MAF fertiliser recommendation models.

\begin{tabular}{|c|c|c|c|c|c|c|c|c|c|}
\hline \multirow{3}{*}{ Soil } & \multirow{3}{*}{ Nutrient } & \multicolumn{4}{|c|}{ Sheep and beef } & \multicolumn{4}{|c|}{ Dairy } \\
\hline & & \multirow{2}{*}{$\begin{array}{c}\text { Maintenance } \\
\text { (kg/ha) }\end{array}$} & \multicolumn{3}{|c|}{ Current } & \multirow{2}{*}{$\begin{array}{c}\text { Maintenance } \\
\text { kg/ha }\end{array}$} & \multicolumn{3}{|c|}{ Current } \\
\hline & & & $\mathrm{kg} / \mathrm{ha}$ & $\%$ nil? & $\mathrm{kg} / \mathrm{ha}(-\mathrm{nil})^{3}$ & & $\mathrm{~kg} / \mathrm{ha}$ & $\% \mathrm{nil}^{2}$ & kg/ha (-nil)' \\
\hline \multirow[t]{3}{*}{ Pumice } & $\mathbf{P}^{4}$ & 16 & 23 & 7 & 25 & 23 & 25 & 14 & 29 \\
\hline & S & 24 & 26 & 10 & 30 & 26 & $17^{5}$ & $38^{5}$ & 29 \\
\hline & K & 25 & 23 & 30 & 32 & 66 & 64 & 12 & 71 \\
\hline \multirow[t]{3}{*}{ All soils } & $P$ & 16 & 21 & 19 & 24 & 25 & 21 & 27 & 29 \\
\hline & S & 21 & 21 & 22 & 20 & 25 & 14 & 42 & 27 \\
\hline & K & 22 & 19 & 41 & 33 & 62 & 61 & 16 & 73 \\
\hline
\end{tabular}

Hay and silage areas need additional inputs.

Percentage of samples with no nutrient recommended.

Mean rate recommended, excluding samples with nil nutrient recommendations.

Recent trial data (B.S. Thorrold, unpublished data) indicates that these rates are underestimates.

See subnote of Table 4 
Trace elements

Requirements for trace elements cannot be determined accurately using soil testing and must be assessed using plant or animal tissue testing. Unfortunately it was not possible to produce a database of trace element analyses for the BOP. Nevertheless, Ledgard et al. (1991) summarised plant analyses by MAF for the whole of the North Island and showed essentially no deficiencies of molybdenum, zinc, iron and manganese for pasture growth. However, 20-30\% of samples showedlow levels of cobalt, copper and selenium which could affect animal health. Pumice soils are renowned for being relatively low incobalt and selenium, andsupplementation (directly to animals or in fertiliser) is often required (A. Frazer, MAF Animal Health Laboratory, pers.comm).

Suitability of slow-release fertilisers

$R P R$

RPRs are currently the cheapest form of $P$ fertiliser per $\mathrm{kg} \mathrm{P}$ but they must dissolve in soil before the $P$ becomes plant-available, and the rate of dissolution is influenced by soil and climatic conditions. Thus, they are not recommended for use on soils with $\mathrm{pH}$ above 6.0 and where annual rainfall is below $800 \mathrm{~mm}$. They are also considered most appropriate as a maintenance fertiliser and not for short-term increases in soil P status and hence in production (Edmeades et al. 1990).

The summary of soil tests for the BOP showed that $91 \%$ of sheep farms and $86 \%$ of dairy farms had soil $\mathrm{pH}$ values 56.0, withlittledifference among soil types. Average annual rainfall in all areas of the BOPexceeds $800 \mathrm{~mm}$ and therefore this is not alimitation for the use of RPR.

Approximately one-third of sheep and one-half of dairy farms in the BOP have soils with $\mathrm{pH} 16.0$ and have current $P$ requirements equal to or less than maintenance Prequirements (Table7). Thel attercriterionofmoderate to high $\mathrm{P}$ status, and therefore low $\mathrm{P}$ responsiveness, means that the 'lag' in P availability from RPR (e.g. Sindair 1990) is less evident in pasture production.

The largest cost-benefit from RPR is obtained where there is no $S$ requirement. This occurs because RPRs contain negligible $S$, in contrast to the more soluble $P$ fertilisers (e.g. superphosphate with $11 \% \mathrm{~S}$ ), and $\mathbf{S}$ must be added to RPR where both $P$ and $S$ are required.

The soil summary for the BOP indicated that about one-eighth of sheep farms and one-quarter of dairy farms met the combined criteria (including no $S$ requirement) for greatest cost-benefit from RPR use (Table 7). These proportions were similar to those for the whole of the North Island for sheep/ beef farms, but were lower for dairy farms.
Table 7 Percentage of farms in various soil test categories for use of RPR as a form of $P$ fertiliser.

$\mathrm{pH} \leq 6.0$ \& $\mathrm{pH} \leq 6.0$ \&

current $P \leq$ maintenance $P$ current $P \leq$ maintenance $P$ $\&$ no $\mathbf{S}$ required

Bay of Plenty

Sheep/beef farms $36 \quad 12$

Dairy farms $\quad 46 \quad 23$

North Island

Sheep/beef farms $37 \quad 13$

$\begin{array}{lll}\text { Dairy farms } & 56 & 39\end{array}$

Elemental $S$

Elemental $S$ is a slow-release form of $S$ fertiliser which must be oxidised by soil bacteria to sulphate $\mathbf{S}$ before it can be utilised by plants. Potentially, elemental $\mathbf{S}$ can be more effective than sulphate as a source of $\mathbf{S}$ on low $\mathbf{S}$ retentive pumice soils where sulphate is readily leached (Hogg 1965). Pumice soils predominate in the BOP and a relatively high proportion of farms is on pumice soils with a below-optimum soil $\mathbf{S}$ test (Table 3 ).

To date, few experiments in the North Island has examined the efficiency of elemental $\mathbf{S}$ and sulphate $\mathbf{S}$ fertilisers at similar rates of $\mathbf{S}$ application. One experiment was on a pumice soil near Rerewhakaaiti (A.G. Sinclair\& W.M.H. Saundersunpublished; Figure 1) and the results showed that sulphur superphosphate (which contained $70 \%$ of its S as elemental S) was more effective at increasing pasture production over 1 to 2 years than superphosphate (which contains sulphate-S only).

These results indicate that fertiliser containing elemental $\mathbf{S}$ (eg. $\mathbf{S}$ super) is desirable as a source of $\mathbf{S}$ for pastures on pumice soils so that $S$ does not become limiting within the year of application, and to avoid large $\mathbf{S}$ losses. It may also be the preferred source of $\mathbf{S}$ on peat soils where leaching losses of sulphate $\mathbf{S}$ can also be large (Hogg 1965). The form of $S$ fertiliser is unimportant on ash soils because little leaching of sulphate $\mathbf{S}$ occurs on these soils.

\section{Conclusions}

The soil test summary clearly showed that a high proportion of sheep and dairy farms in the BOP have low levels of $\mathrm{P}, \mathrm{S}$ or $\mathrm{K}$ in soil which would limit pasture production. It was estimated that economically worthwhile increases in production through application of fertiliser $P, S$ and $K$ would occur on about 50-70\% of farms in the short-term (1 to 2 years).

Pasture production on most farms was limited by more than one nutrient. On an individual farm, soil testing should be used to identify the main limiting 


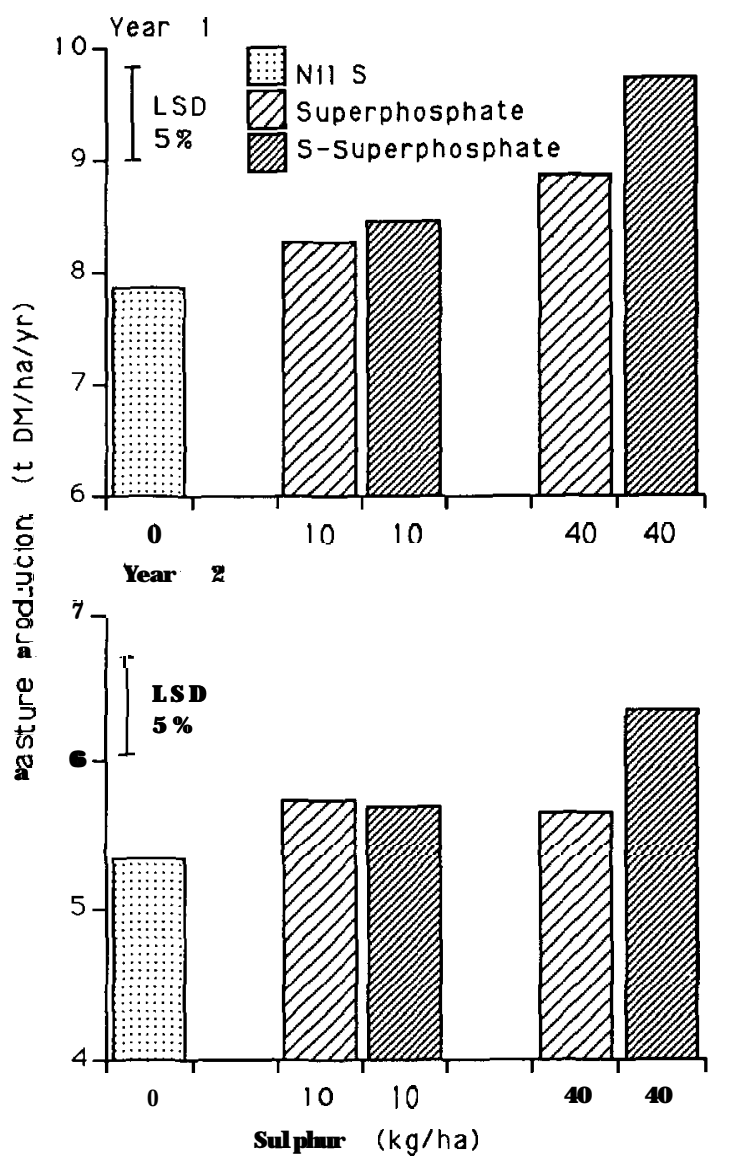

Figure 1 Effect of form and rate of sulphur on pasture production on a pumice soil near Rerewhakaaiti (A. G. Sindairand W.M.H. Saunders unpublished). Superphosphate contained all of its sulphuras sulphate whereas $S$-superphosphate contained $2 / 3$ elemental $S$ and $1 / 3$ sulphate S. All plots received adequate $\mathbf{P}$.

nutrient(s) and ensure cost-effective use of fertiliser. Soil testing should also be used if RPRs are being considered, to check that soil $\mathrm{pH}$ and $\mathrm{P}$ status are appropriate and to check whether $S$ addition is required.

A larger proportion of pumice soils, compared with other soil types, had low soil test levels for $\mathrm{P}, \mathrm{S}$ and $\mathrm{K}$, indicating the important need for these nutrients in fertiliser to maintain production. On pumice soils, leaching of sulphate $\mathbf{S}$ can be large and fertilisers containing elemental $\mathbf{S}$ (a slow-release form) are preferable for ensuring that plants have an adequate supply of $S$ throughout the year.

\section{ACKN OW LEDGEMENTS}

We thank the MAF Soil Fertility Service for use of data from soil analyses, and Drs A. G. Sinclair and
W.M.H. Saunders for permission to use unpublished trial data.

\section{REFERENCES}

Clark, D.A.; Ledgard, S.F.; Lambert, M.G.; O'Connor, M.B.; Gillingham, A.G. 1990. Long term effects of withholding phosphate application on North Island hill country: Economics. Proceedings of the NZ Grassland Association 51: 29-33.

Cornforth, I.S.; Sinclair, A.G. 1984. Fertiliser recommendations for pastures and crops in New Zealand. Wellington, MAF.

Edmeades, D.C.; Pringle, R.M.; Mansell, G.P.; Shannon, P.W. 1984. Effects of lime on pasture production on soils in the North Island, N ew Zealand 4. Predicting lime responses. NZ Journal of agricultural research 27: 371-382.

Edmeades, D.C.; Cornforth, I.S.; Roberts, A.; Shannon P.W. 1988. MAFTech Soil Fertility Serviceputting science into fertiliser advice. Proceedings of the 40th Ruakura Farmers' Conference: 27-32.

Edmeades, D.C.; O'Connor, M.B.; Ledgard, S.F.; Roberts, A.H.C.; Thorrold, B. 1990. Fertilisers facts and fallacies. Proceedings of the 42ndRuakura Farmers' Conference: 46-54.

Hogg, D.E. 1965. Studies on leaching losses of sulphur from pumice soils, yellow brown loams and sands. Proceedings of the NZ Grassland Association 27: 123-128.

Ledgard, S.F.; O'Connor, M.B.; Edmeades, DC.; Thorrold, B.S. 1991. Getting it right with the soil and pasture - cost effective use of fertiliser. Proceedings of the 43rd Ruakura Farmers' Conference: 83-89.

O'Connor, M.B.; Smart, C.E.; Ledgard, S.F. 1990. Long term effects of withholding phosphate application on North Island hill country: Te Kuiti. Proceedings of the NZ Grassland Association 51: 2 l-24.

Roberts, A.H.C.; Edmeades, D.C.; O'Connor, M.B.; Thomson, N.A. 1991. The importance of fertiliser formilkproduction. Proceedings of the 43 rdRuakura Farmers' Conference: $60-66$.

Sinclair, A.G. 1990. Long term effectiveness of reactive phosphate rock as a phosphate fertiliser for $\mathrm{New}$ Zealand pastures. Proceedings of the NZ Grassland Association 51: 101-104.

Sinclair, A.G.; Boswell, C.C.; Comforth, I.S.; Lee, A.; Morgan, C.; Morton, J.; N guyen, L.; Saunders, W.M.H.; Shannon, P.; Smith, R.G.; Whelan, G. 1985. Agronomic requirements for sulphur in New Zealand pastures. Proceedingsof the 20th Technical Conference of the N.Z. Fertiliser Manufacturers' Research Association 2: 538-572. 